\title{
Mediation Role of Attitude towards Product Placement in Social Media
}

\author{
Azaze-Azizi Abdul Adis ${ }^{1}$, Grace Phang Ing ${ }^{1}$, Zaiton Osman ${ }^{1}$, Izyanti Awang Razli ${ }^{1}$, Yi Xuan Pang ${ }^{1}$, Stephen \\ Laison Sondoh Jr. ${ }^{1} \&$ Mohd Rizwan Abdul Majid ${ }^{1}$ \\ ${ }^{1}$ Faculty of Business, Economics and Accountancy, Universiti Malaysia Sabah, Kota Kinabalu, Sabah, Malaysia \\ Correspondence: Azaze-Azizi Abdul Adis, Faculty of Business, Economics and Accountancy, Universiti \\ Malaysia Sabah, Jalan UMS, 88400, Kota Kinabalu, Sabah, Malaysia. Tel: 60-88-320-000 Ext. 1576/1171. E-mail: \\ azizi@ums.edu.my; azizi_azazea@hotmail.com
}

Received: January 30, 2015 Accepted: March 5, 2015 Online Published: May 28, 2015

doi:10.5539/jsd.v8n3p79

URL: http://dx.doi.org/10.5539/jsd.v8n3p79

\begin{abstract}
The present paper empirically examines consumer attitude and behavioral intention structures in social media context, particularly focusing on Gen Ys who are the world's largest population group. Three antecedent factors (i.e. perceived relevance, perceived value and perceived credibility) were closely examined for their influences on attitude towards product placement (App) and purchase intention. App was proposed to serve as a mediator between these antecedent factors and purchase intention. The mediation results indicated that perceived relevancy and perceived credibility affect purchase intention in two ways: directly and indirectly through App. Meanwhile, perceived value only has a significant direct effect on purchase intention. Consumers considered perceived relevance and perceived credibility as antecedents to App, but not perceived value. The findings provide useful insight to both marketers and academicians in planning for their promotion strategy.
\end{abstract}

Keywords: attitude, product placement, social media, Generation Y

\section{Introduction}

With more than 3 billion people assessing to internet this year (Internet Live Stats, 2014/12/1), popular social networking sites such as Facebook, Twitter and Instagram are reaching out to people across different socio economic layers, notably among the generation Ys (Pew Internet Research Project, 2014). Social networking has become a global phenomenon with its advantages of high speed connections, credibility, ease of use with more visual and attention catching features (Kostkova, de Quincey \& Jawaheer, 2010, Malka, 2012). People use social media to create relationship (Safko \& Brake, 2009), facilitate communication and interaction (Pew Internet Research Project, 2014), share and discuss ideas and information (Best, Manktelow \& Taylor, 2014; Moise \& Cruceru, 2014).

Realizing its great potential, marketers have shifted their attention to social media. Product placement which is an integration of a brand or product into entertainment (Russell \& Belch, 2005) has gained popularity in social media context (La Ferle, Steven \& Lee, 2008; Lee \& Faber, 2007). It is a promotional technique that uses products or brands in either fictional or non-fictional situations (Gutnik, Huang, Lin \& Schmidt, 2007), or uses as an identity within the entertainment media programming (Lee \& Faber, 2007). As it is normally not under the direct control of the marketers but rather some creations by someone else (van Reijmersdal, Neijens \& Smit, 2009), product placement is said to be able to reach consumers' minds and enhance positive brand feelings (Babacan, Akcalu \& Baytekin, 2012). As such, it is easier for product placement to create consumer awareness and increase interests toward the products or brands which further affect consumer behavior (Babacan et al., 2012; Newell, Salmon \& Chang, 2006).

Product placement has been existed for more than 70 years (Babacan et al., 2012). Unfortunately, more than half of the published studies on product placement effects are studies in the last five years, focusing on product placement in traditional media such as television programs and movies. As product placement is getting more important in academic research area (Balasubramanian, Karrh \& Patwarahan, 2006; Wilson \& Till, 2011) as well as to marketing practitioners, there is a need to study the impacts and effectiveness of product placement. Notably, product placement has started to shift to new media (La Ferle et al., 2008; Lee \& Faber, 2007) such as social networking; there is a need for research on further examining product placement in social media context. 
Finally, the lack of studies on product placement in Malaysia context also addresses an opportunity for future study (Abdul Adis \& Kim, 2013).

In addition to the examinations on the relationships between the three antecedent factors namely perceived relevance, perceived value and perceived credibility on purchase intention, the present paper further investigates the roles of attitude towards product placement (App) in mediating the relationships between these antecedent factors and purchase intention. The results provide valuable insights to both marketing practitioners and academicians in understanding the relationships between the antecedent factors and purchase intention. The attitude-behavioral intention link is examined in a more detailed manner and the direct and indirect influences on purchase intention could also be further identified.

\subsection{Social Media and Generation Y}

Generation Y (Gen Y) or Millennial or Net Generation constitutes the world's largest population group (Malka, 2012). Traditional media such as TV and newspaper are found to be obsolete towards these young consumers (Pinzaru, Savulescu \& Mitan, 2013; Rutsaert, Pieniak, Regan et al., 2014) and even worse; many young consumers find ads to be unattractive and a kind of distraction. Zipping and zapping are common and the habits of switching channel or skipping commercials lead to failure in marketing communication. It is hence important for marketers to understand the young consumers' mindsets, values and purchase behaviors (W5 Insight, 2008). Marketers need to switch to alternative channels to promote their products and services in planning for their marketing communication strategy whenever necessarily. In fact, this is what leads to the birth of product placement (Gutnik et al., 2007) as a valid and valuable way of reaching consumers.

As the Generation Ys are highly brand conscious, they are not easily rely on marketing and advertising claims. Instead, they prefer to search for information via internet, blogs and peer relationships. Through social networking, Gen Ys are able to express their ideas and opinions, keep in touch with peers in the networking groups and build professional contact networks. They also spend more time on social networking sites (SNS) than any other groups. In other words, they have higher chance to be exposed to product placement in SNSs, implying huge marketing implications (Kotler \& Armstrong, 2010).

\subsection{The Antecedent Factors and the Mediation Role of Attitude towards Product Placement}

The review of the ad relevancy literature indicates contradicting findings on the relationship between perceived relevance and attitude. Some propose that high relevancy leads to positive feelings or attitudes toward an advertisement (Varnali, Yilmaz \& Toker, 2012). For instance, the advergames researchers found that advertising position in the games induces higher purchase intention as the product placement enhances the reality of the games (Phang \& Abdul Adis, 2009). However, others found that incongruent game billboard is much more remembered over the congruent ones (Huang \& Yang, 2012). Huang and Yang conclude that people remember better the advertisement that is low in relevancy within the gaming environment. It is hence a better strategy to have irrelevant advertisement in games (Huang \& Yang, 2012). These contradicting findings in advergames and advertising studies cause confusion and questions whether a similar scenario is experienced in social media.

In social media, consumers are expected to behave differently based on the perceived ad relevancy. People generally behave positively when the perceived relevancy is high $(\mathrm{Ng}, 2013)$ due to strong sense of clones, familiarity and presence of trust in using a particular social networking site. An advertisement is perceived as relevant when it is important and meaningful (Drolet, Williams \& Lau-Gesk, 2007) or appropriate and applicable to the target customers (MacInnis \& MacInnis, 1989). Similarly, Wang, Yu \& Wei (2012) also supported the importance of socialization purchasing decision that significantly contributed to ad relevancy. Social connections on social networking sites affect consumer purchasing decisions (Wang \& Chang, 2013). Perceived online ad relevance has the potential to deliver highly targeted advertising that match the decision context of the online users (Hunt, 1998). Greater congruency to the social identities is formed from relevant advertisements which then lead to positive impacts on consumers' product attitude and purchase decision (Zeng, Huang \& Dou, 2010). Chi et al. (2013) also found supporting results for perceived value as a significant factor in influencing consumers' purchase decision process with higher perceived value led to higher intention to buy.

As consumers are spending much time on SNSs nowadays, these SNSs clearly show great opportunity for marketers to target their customers, utilizing more targeted advertisements. In other words, greater perceived relevance leads to more positive attitude and higher buying intention. As the true psychological impacts of the relevancy are believed to be captured by the attitudes toward the product placement, attitude will serve the mediation role in influencing buying behavior. When consumers perceive a product placement to be valuable, useful and important, their attitudes toward the product placement eventually influence their buying intention (Liu et al., 2012). 
Product placement in social media creates an opportunity for exchange of ideas and experiences between the peer consumers and between the marketers and consumers. Consumers in particular receive great value from this communication process. Perceived value is found to be a significant indicator to consumers' online purchase behavior (Chi, Yeh, Chien \& Tsai, 2013; Wang, Yeh \& Liao, 2013) which influenced by the perceived enjoyment, usefulness, perceived fee and ease of use. When it is perceived as enjoyable and entertaining, consumer attitudes towards product placement will be more favorable, and in turn influence purchase intention (Wang et al., 2013).

Brand is said to bring value to consumers, especially in creating product differentiation. In most cases, consumes learn about brand value through marketing communication such as advertisement. Numerous studies indicate the importance of perceived value on consumer attitudes and behavioral intention. Beneke (2002) for instance, found that people put greater emphasis on the interactivity and media richness in the context of social media when forming their attitudes toward the advertisement and behavioral intention. High interactivity and media richness lead to higher perceived value and in turn, higher purchase intention. Other researchers such as Wang and Chang (2013) proposed high diagnosticity to be able to reduce perceived risk and increase purchase intention as people generally put more weights on information or recommendations made by people they are close to. This information is treated as more useful and important (Ducoffe, 1995; Liu, Sinkovic, Pezderka \& Haghirian, 2012). Others proposed that product placement in SNSs should be viewed as more interesting than traditional media (Motwani, Shrimali \& Agarwal, 2014), hence induce positive feelings and evaluations. The attitude that consumers form toward product placement will serve as a mediator in affecting the relationship between perceived value and purchase intention.

The availability of huge amount of information and the opportunity for the customers to share their views and opinions online also add to the value of product placement in social media context. Different from product placement in traditional media, consumers are able to exchange views and opinions (Lee, 2013) and actively search for information and treated this process as more reliable and transparent in SNSs. Therefore, it is clear that credible source leads to formation of positive consumer attitudes (Yogci et al., 2009). Through social media, product information are delivered and discussed among the communities. Important information could be gathered as customers' views and opinions can be accessed through social relationships (or social commerce, Wang \& Chang, 2013). In MacKenzie \& Lutz's (1989) study, advertisement is said to be credible when it is perceived to be convincing, believable and credible. In particular, high trust and credibility towards brand should lead to more positive attitude, and eventually higher buying intention (Jiménez \& Mendoza, 2013).

However, the availability of the huge amount of information also leads to difficulty in differentiating the credible sources from not credible ones. In addition, consumers could have formed higher skepticism towards the product placement as well as the sponsored recommendations due to the speculation of favorable comments and messages by the so called 'sponsored peer users' or 'sponsored bloggers' by marketers (Lu, Chang \& Chang, 2014). Trust and credibility are hence vital and essential issues in influencing consumer behavior (Lu et al., 2014). Positive evaluative thoughts on credibility contribute significantly to consumer attitudes (Yagci, Biawas $\&$ Dutta, 2009). Consumers perceive a highly convincing and believable advertisement to have higher credibility, which help in forming their attitudes toward the product placement and in turn, affect their purchase intention.

In conclusion, it is postulated in this study that the three antecedent factors will significantly influence the attitude towards product placement and purchase intention; while attitude towards product placement will serve the mediation roles in the relationships between these antecedent factors and purchase intention:

H1: Perceived relevance significantly influences attitude towards product placement and purchase intention.

$\mathrm{H} 2$ : Perceived value significantly influences attitude towards product placement and purchase intention.

H3: Perceived credibility significantly influences with attitude towards product placement and purchase intention.

H4: Attitude towards product placement has significant relationship with purchase intention.

H5: Attitude towards product placement mediates the relationship between perceived relevance and purchase intention.

H6: Attitude towards product placement mediates the relationship between perceived value and purchase intention.

H7: Attitude towards product placement mediates the relationship between perceived credibility and purchase intention. 


\section{Method}

The present study employs convenience sampling method as it is the most efficient way to obtain information from respondents (Sekaran \& Bourgie, 2011). A total of 210 usable questionnaires were collected for data analysis, distributed manually and through online contacts. Online questionnaires are utilized as it is a preferable option to target respondents due to its convenience and high accessibility. By employing the guideline recommended by Hair, Black, Babin, Anderson \& Latham (2006), the minimum sample size requirement should be five (i.e. number of responses) times of the number of variables, the present sample size of 210 is considered as appropriate.

The respondents in the present study came from various ethnicity backgrounds, with special attention paid to on age distribution. The selection of the age groups is based on several rationales. The review of the literature indicates that the majority of the SNSs users are young adults aged between18-35 (Pew Research Internet Project, 2014). Students especially, are found to spend the highest amount of time accessing SNSs in a day (Mao, 2014). The respondents in this study who were mainly Chinese (70\%) aged between $18-25$ year old $(53 \%)$ and have at least university degree (55\%), were considered to be appropriate.

The perceived relevancy was measured with a 5 item-five point scale, adopted from Drolet et al. (2007) and MacInnis \& Jaworski's (1989) studies; perceived value was measured with a 3 item-five point scale, adopted from Ducoffe et al. (1995) and Liu et al.'s (2012) studies; perceived credibility was measured with a 5 item-five point scale, adopted from Mackenzie \& Lutz (1989) and Xu's (2007)'s studies. Finally, attitude towards product placement and purchase intention were both utilizing the 6 item-five point scales from Park, MacInnis, Priester, Eisingerich \& Iacobucci (2006) and Bouhlel et al.'s (2010) studies.

Multiple regression analysis was utilized to test the relationship between antecedent factors and purchase intention. Smart PLS M2 Version 2.0 software was used to analyze the model as well as the mediation analysis with the application of a bootstrapping technique to determine the significance levels for loadings, weights, and path coefficients (Ramayah, Jasmine \& Ignatius, 2013).

\section{Findings}

First of all, the data were run for reliability and validity tests. In PLS, loadings of factors on their respective constructs are examined to assess the reliability of the factor, factors that have factor loadings of less than .5 shall be removed (Hulland, 1999). All constructs were found to have loadings higher than .70, suggested by Hair et al. (2006). The constructs also had acceptable Cronbach's alpha coefficients, namely .792 for attitudes toward product placement (App), .930 for perceived credibility, .941 for perceived relevance, and .945 for both perceived value and purchase intention. Next, AVEs for all constructs were calculated and cross-checked. The calculated AVEs were found to be above acceptable level of .05 (Bagozzi, 1981), namely .877 for App, .782 for perceived credibility, .770 for perceived relevance, .859 and .901 for perceived value and purchase intention respectively. The calculated composite reliabilities were found to be higher than 0.7 (Fornell \& Larcker, 1981), namely .977 for App, .947 for perceived credibility, .952 for perceived relevance, .961 for perceived value and .965 for purchase intention.

Table $1 . \mathrm{R}^{2}$ and goodness of fit indices

\begin{tabular}{lcc}
\hline Endogenous Constructs & $\mathbf{R}^{2}$ & AVE \\
\hline PERCEIVE RELEVANCE & .770 \\
PERCEIVE VALUE & .859 \\
PERCEIVE CREDIBILITY & .782 \\
APP & .708 & .877 \\
PURCHASE INTENTION & .781 & .901 \\
\hline Average & .745 & .838 \\
\hline GoF $=\sqrt{\overline{R^{2}} x \overline{A V E}}$ GoF $=\sqrt{0.624} \sqrt{0.317} \mathrm{GoF}=.790 \sqrt{0.272} \sqrt{\overline{\mathrm{R}^{2}} \times \overline{\mathrm{AVE}}}$ (Tenenhaus et al., 2005) \\
\hline
\end{tabular}

As recommended by Fornell \& Cha (1994) and Fornell \& Larcker (1981), AVE of each construct should be higher than the correlation between it and any other constructs of the model in order to achieve discriminant 
validity. The examinations of the data met this criterion. The values are higher than the correlations between itself and any other constructs in the model, indicating acceptable discriminant validity, namely .936 for App, .884 for perceived credibility, .877 for purchase intention, .927 for perceived relevance, and .949 for perceived value.

The $\mathrm{R}^{2}$ value for the attitude towards product placement (App) in social media (APP) indicated that 70.8 percent of the variance in attitude was significantly explained by all of the exogenous latent variables, namely perceived relevance (PAR), perceived value (PAV) and perceived credibility (PAC). Meanwhile for the purchase intention (PURCHASE INTENTION), the $\mathrm{R}^{2}$ indicated 78.1 percent of the variance in purchase intention was significantly explained by all of the exogenous latent variables. Furthermore, the calculated Goodness-of-Fit (GoF) value was .790 , which exceeds the cut off value of .36 for large effect sizes of $\mathrm{R}^{2}$. GoF is the geometric mean of the average communality and the average of $\mathrm{R}^{2}$ that represents the overall fit of the model (Tenenhaus et al., 2005). In brief, the current model achieved acceptable reliability, validity and goodness of fit.

For the hypothesis testing, the results of the multiple regression analysis showed significant relationships between perceived relevance $(\beta=.249, \mathrm{t}=3.672, \mathrm{p}<.0001)$ and perceived credibility $(\beta=.577, \mathrm{t}=.7389, \mathrm{p}<.0001)$ on App, except perceived value $(\beta=.249, \mathrm{t}=.843, \mathrm{p}=.40)$. The three antecedent factors $\left(\beta_{\mathrm{PAR}}=.188, \mathrm{t}=2.469\right.$, $\left.\mathrm{p}<.05 ; \beta_{\mathrm{PAV}}=.190, \mathrm{t}=2.519, \mathrm{p}<.05 ; \beta_{\mathrm{PAC}}=.466, \mathrm{t}=5.3, \mathrm{p}<.0001\right)$ on the other hand, had significant influences on purchase intention. The results hence fully supported hypotheses 1 and 3 , and partially supported hypothesis 2 . The path model indicated in Figure 1 indicated that there was a positive relationship $(\beta=.683, \mathrm{p}<.01)$ between attitude towards product placement and purchase intention, supporting hypothesis 4 .

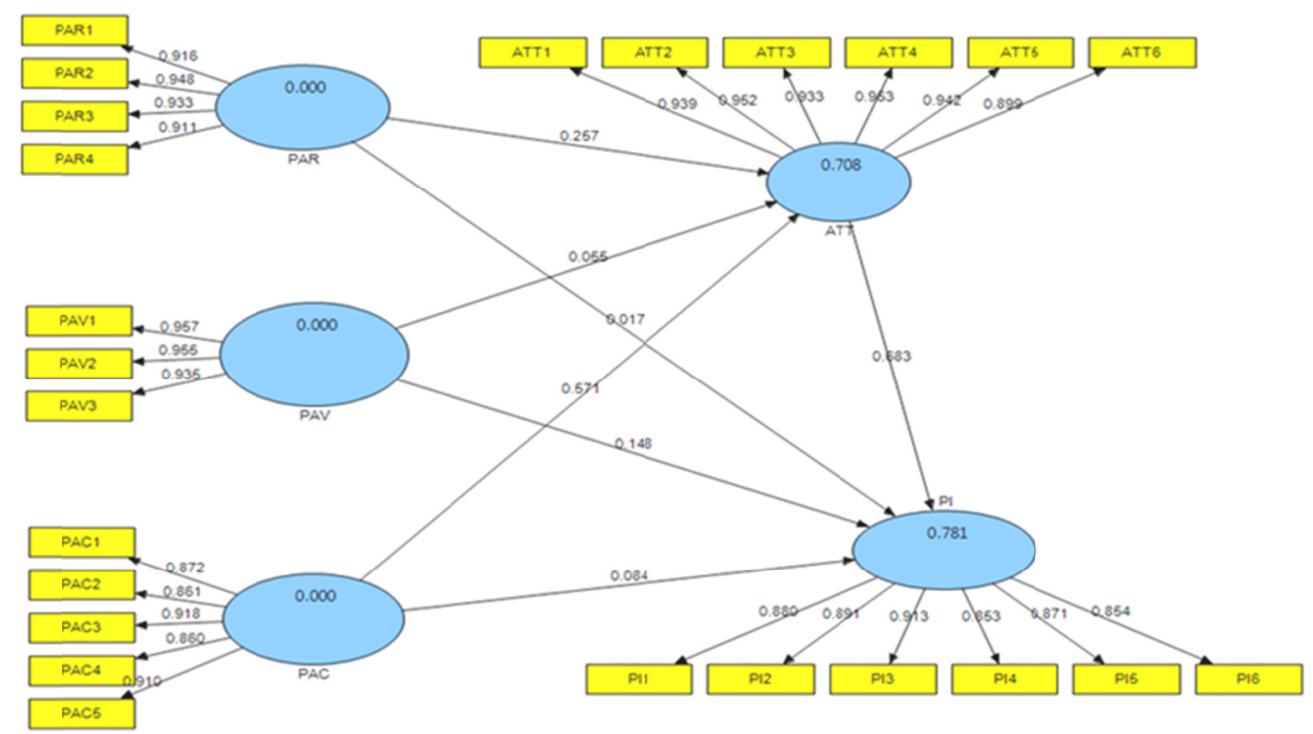

Figure 1. Path model

Secondly, the results of the mediation tests indicated that perceived relevancy and perceived credibility affect purchase intention in two ways: directly and indirectly through attitude towards product placement. Meanwhile, perceived value only has a significant effect on purchase intention but not App. In particular, there was a positive significant relationship between perceived relevance and App $(\beta=.257, t=3.482, p<.01)$. However, there was no significant relationship found between perceived relevance and purchase intention $(\beta=.017, \mathrm{t}=.203)$. Referring to Table 2, the bootstrapping analysis for perceived credibility-App-PI link indicated an indirect effect of $\beta$ $=.390(.571 * .683)$ was significant with a t-value of 6.018. As indicated by Preacher and Hayes (2008), with an indirect effect of $.390,95$ percent Boot CI: $[\mathrm{LL}=.263, \mathrm{UL}=.517]$ did not straddle a 0 in between. These results indicated a mediation effect, hence supporting hypothesis 5 .

As for perceived credibility, similar results were gathered. There was a significant relationship found between relevance and attitude $(\beta=.571, \mathrm{t}=6.778, \mathrm{p}<.01)$. However, there was no significant relationship between relevance and purchase intention $(\beta=.084, \mathrm{t}=1.118)$. The bootstrapping analysis of perceived relevance-App-PI link in Table 2 showed that the indirect effect of $\beta=.176\left(.257^{*} .683\right)$ was significant with a t-value of 3.189. In addition, 95 percent Boot $\mathrm{CI}$ : $[\mathrm{LL}=.068, \mathrm{UL}=.284]$ did not straddle a 0 in between, indicating a mediation 
effect, hence supporting hypothesis 6 .

Perceived value is found to have no significant relationship with attitude $(\beta=.055, \mathrm{t}=0.76)$, but with purchase intention $(\beta=.148, \mathrm{t}=2.493, \mathrm{p}<.01)$. The bootstrapping analysis for perceived value-App-PI link showed that the indirect effect of $\beta=.038\left(.055^{*} .683\right)$ was insignificant with a t-value of .740 . The indirect effect of .038 with 95 percent Boot CI: $[\mathrm{LL}=-.062, \mathrm{UL}=.139]$ straddled a 0 in between, indicating no mediation effect. The results hence did not support hypothesis 7.

Table 2. Mediation tests results

\begin{tabular}{|c|c|c|c|}
\hline Relationship & Indirect Effect & Confidence Level & Decision \\
\hline Perceived Credibility -> App -> PI & $\begin{array}{l}.571^{*} .683 \\
=.390\end{array}$ & $\begin{array}{l}\mathbf{L L} \\
=.39-1.96^{*}(.065) \\
=.263 \\
\mathbf{U L} \\
=.39+1.96 *(.065) \\
=.517\end{array}$ & Mediation \\
\hline Perceived Relevance -> App -> PI & $\begin{array}{l}.257 * .683 \\
=.176\end{array}$ & $\begin{array}{l}\mathbf{L L} \\
=.176-1.96 *(.055) \\
=.068 \\
\mathbf{U L} \\
=.176+1.96 *(.055) \\
=.284\end{array}$ & Mediation \\
\hline Perceived Value -> App -> PI & $\begin{array}{l}.055^{*} .683 \\
=.038\end{array}$ & $\begin{array}{l}\mathbf{L} \mathbf{L} \\
=.038-1.96 *(.051) \\
=-.062 \\
\mathbf{U L} \\
=.038+1.96 *(.051) \\
=.139\end{array}$ & No Mediation \\
\hline
\end{tabular}

\section{Discussion, Limitation and Conclusions}

Media proliferation has increased the need to effectively communicate with target markets. Generation Ys as the largest world population group implies huge market implication that heightens their importance. They will continue to make online sharing in networks a lifelong habit, even as they mature and have families (Pew Internet Research Project, 2014). The advancement of technology allows this group of consumers to be accessible to huge amount of information. Marketers hence need to carefully plan their marketing communication strategy to be seen as interesting and important to them. With more than $74 \%$ of the online adults using SNSs nowadays (Pew Internet Research Project, 2014), product placement in social networking sites (SNSs) could be one of the useful tools. Unfortunately, academic studies on product placement in SNSs are still at their infant stage, leading to confusion and uncertainties.

The current paper fills in the gap by examining the factors that contributes to consumer attitudes toward product placement and eventually the influence on consumer purchase intention. It is proclaimed that there are significant influences of the three antecedent factors, namely perceived reliability, perceived value and perceived credibility on attitude towards product placement (App) and purchase intention.

The results of the multiple regression analysis provided support for hypotheses 1 and 3, but not hypothesis 2 . Specifically, perceived relevance was positively associated with App in social media, consistent with the past research (Ng, 2013; Varrnali et al, 2012). It is believed that Malaysian consumers nowadays are more educated and have higher willingness to explore new things, especially among the Gen Ys who born in the technology era. People have more favorable attitudes when the product placement is perceived as important, meaningful, appropriate and applicable (Drolet et al., 2007; MacInnis \& Jaworski, 1989). Most importantly, high congruency 
to social identities also leads to positive attitudes (Zeng et al., 2010). Consistent with Zeng et al. (2010), the findings also supported the relationship between perceived relevance on purchase intention.

Similarly, multiple regression analysis showed that perceived credibility had a significant association with App, consistent with previous studies (Sallam, 2011; Doss, 2011). Credible sources lead to formation of positive consumer attitudes (Yogci et al., 2009). As consumers have the freedom to search for information and evaluate product/brands through peer consumers' reviews in SNSs (Wang and Chang, 2013), this information is treated as more credible and useful to form positive attitude. Credibility also found to contribute significantly to purchase intention, consistent with Jiménez \& Mendoza's (2013) study that trust and credibility are important to form higher purchase intention.

However, multiple regression analysis results revealed that the perceived value did not have a significant relationship with App, but a significant influence on purchase intention. The positive relationship between perceive value and purchase intention is consistent with the past research in social media literature (Wang et al. 2013; Zeng et al., 2009). For product placement in social media context, a greater perceived value such as the degree of message exposures and perceived enjoyment and entertainment stimulate positive evaluations among the targeted respondents that directly affect their purchase intention. Rather than contributing to the attitude formed, perceived value directly influences purchase intention.

Hypothesis 4 specifically addressed the attitude-behavioral intention relationship. The results indicated that App significantly influenced behavioral intention, in which positive attitude led to higher purchase intention. This result is consistent with the previous studies in product placement as well as social media (Abdul Adis \& Kim, 2013; Ghorban, 2012).

The next issue concerns the role of App as a valid mediator. The results of the mediation tests indicated that App served the mediation roles between perceived credibility and perceived relevancy on purchase intention, but not between perceived value and purchase intention. For perceived relevance and perceived credibility, the results shown that the relationships between perceived relevance and perceived credibility with purchase intention can be both direct and indirect through the mediation of attitude dimension (i.e. App). By referring to the mediation analysis in Table 2, it is indicated that perceived relevancy indirectly influence purchase intention when App is considered. It is only through the attitudes that consumers form toward product placement that perceived relevancy influence purchase intention. Similarly, for perceived credibility, the difficulty in differentiating the credible and not credible sources could have caused perceived credibility not to have direct influence on purchase intention, when App is considered. For instance, people are skeptical toward the 'sponsored peer reviews' or 'sponsored recommendations' favoring the marketers who sponsored the brands/products. These along underline the importance of perceive relevance and credibility in determining the purchase intention of social media among young Malaysian consumers.

The results from the present paper make several contributions. From the theoretical perspective, the present paper contributes to the purchase intention literature in support of the relationships between the three antecedent factors, attitude and purchase intention of product placement in social media context. The obtained results also contribute to the existing consumer behavior literatures by empirically examining the mediating role of attitude on the relationships between the three antecedent factors and purchase intention. In particular, perceived relevance, value and credibility are found to have different impacts on attitudes toward product placement and purchase intention. Relevancy and credibility are important factors contributing to the forming of attitudes toward product placement, meanwhile perceived value is not. On the other hand, the former two factors have both direct and indirect impacts on purchase intention, meanwhile perceived value only have a direct impact on purchase intention.

In conclusion, the results of the present study suggest the emergence of the social media and product placement as a prevalent idea to marketers. It is important to realize the need to change the conventional marketing strategies to include social media as an effective communication platform between marketers and consumers. Looking into the current trend among the Gen Ys, social media is effective and essential to bridge the connection between business and young consumers, something that is no longer to be achieved by the traditional media.

\section{References}

Abdul Adis, A. A., \& Kim, H. J. (2013). The mediating role of brand recall and attitude towards purchase intention in influencing purchase intention in advergames. Asia Marketing Journal, 15(3), 117-139.

Babacan, E., Akcalu, S. I., \& Baytekin, E. P. (2012). Product placement as a rising marketing communication activity: assessment on television serials. Procedia-Social and Behavioral Sciences, 62, 1319-1331. 
http://dx.doi.org/10.1016/j.sbspro.2012.09.226

Bagozzi, P. R. (1981). Evaluating structural equation models with unobservable variables and measurement error: A comment. Journal of Marketing Research, 375-381. http://dx.doi.org/10.2307/3150979

Balasubramanian, S. K., Karrh, J. A., \& Patwardhan, H. (2006). Audience response to product placements: An integrative framework and future research agenda. Journal of Advertising, 35(3), 115-141. http://dx.doi.org/10.2753/JOA0091-3367350308

Beneke, J. (2002). The facebook effect: An analysis of beer drinkers' perception of brands in an online environment. Retrieved from http://www.wbiconpro.com/504-Justin.pdf

Best, P., Manktelow, R., \& Taylor, B. (2014). Online communication, social media and adolescent wellbeing: A systematic narrative review. Children and Youth Services Review, 41, 27-36. http://dx.doi.org/10.1016/j.childyouth.2014.03.001

Bouhlel, O., Mzoughi, N., Ghachem, M. S., \& Negra, A. (2010). Online purchase intention- understanding the blogosphere effect. International Journal of e-Business Management, 4(2), 37.

Chi, H. K., Yeh, H. R., Chien, S., \& Tsai, Y. C. (2013). The influences of perceived value on consumer purchase intention: The moderating effect of advertising endorser. Retrieved December 10, 2014, from http://www.jimsjournal.org/13percent 20Yipercent 20Chingpercent 20Tsai.pdf

Doss, S. (2011). The Transference of Brand Attitude: The Effect on the Celebrity Endorser. Journal of Management and Marketing Research, 7(1), 58-70.

Drolet, A., Williams, P., \& Lau-Gesk, L. (2007). Age-related differences in responses to affective vs. rational ads for hedonic vs. utilitarian products. Marketing Letters, 18(4), 211-221. http://dx.doi.org/10.1007/s11002-007-9016-z

Ducoffe, R. H. (1995). How consumers assess the value of advertising. Journal of Current Issues \& Research in Advertising, 17(1), 1-18. http://dx.doi.org/10.1080/10641734.1995.10505022

Fornell, C., \& Cha, J. (1994). Partial Least Squares. In R. P. Bagozzi (Ed.), Advanced Methods of Marketing Research (pp. 52-78). Cambridge, MA: Blackwell.

Fornell, C., \& Larcker, D. F. (1981). Evaluating structural equation models with unobservable variables and measurement errors. Journal of Marketing Research, 18(1), 39-50. http://dx.doi.org/10.2307/3151312

Ghorban, Z. S. (2012). Attitude towards product advertisements in social media, its antecedents and consequences: Investigation into smartphone brands in malaysia. Journal of Business and Management, 2(3), 31-35.

Gutnik, L., Huang, T., Lin, J. B., \& Schmidt, T. (2007). New trends in product placement. Strategic Computing and Communication Technology. Retrieved November 9, 2013, from http://people.ischool.berkeley.edu/ hal/Courses/StratTech07/Tech/Preso/D-placement.doc

Hair, J. F., Black, W. C., Babin, B. J., Anderson, R. E., \& Latham, R. L. (2006). Multivariate data analysis (6th ed.). Upper Saddle River, New Jersey: Prentice Hall.

Huang, J. H., \& Yang, T. K. (2012). The effectiveness of in-game advertising: the impacts of ad type and game/ad relevance. International Journal of Electronic Business Management, 10(1), 61-72.

Hulland, J. (1999). Use of partial least squares (pls) in strategic management research: A review of four recent $\begin{array}{lllll}\text { studies. Strategic } & \text { Management }\end{array}$ http://dx.doi.org/10.1002/(SICI)1097-0266(199902)20:2<195::AID-SMJ13>3.0.CO;2-7

Hunt, B. (1998). Targeting advertising age. Supplement Online Media, 69, 38-41.

Internet Live Stats. (n. d.). Retrieved December 1, 2014, from http://www.internetlivestats.com/watch/internet-users/

Jiménez, F. R., \& Mendoza, N. A. (2013). Too popular to ignore: The influence of online reviews on purchase intentions of search and experience products. Journal of Interactive Marketing, 27(3), 226-235. http://dx.doi.org/10.1016/j.intmar.2013.04.004

Kostkova, P., de Quincey, E., \& Jawaheer, G. (2010). The potential of social networks for early warning and outbreak detection systems: The swine flu twitter study. International Journal of Infectious Diseases, 14, 384-385. http://dx.doi.org/10.1016/j.ijid.2010.02.475 
Kotler, P., \& Armstrong, G. (2010). Principle of marketing (3rd ed.). Englewood Cliff, NJ: Prentice Hall.

La Ferle, C., Edwards, S. M., \& Lee, W. N. (2008). Culture, attitudes, and media patterns in China, Taiwan, and The U.S.: Balancing standardization and localization decisions. Journal of Global Marketing, 21(3), 191-205. http://dx.doi.org/10.1080/08911760802152017

Lee, E. (2013). Impacts of social media on consumer behavior-decision making process. Retrieved December 5 , 2014, from https://www.theseus.fi/bitstream/handle/10024/62367/Lee_Ethel.pdf?sequence=1

Lee, M., \& Faber, R. J. (2007). Effects of product placement in online games on brand memory: A perspective of limited: Capacity model of attention. Journal of Advertising, 36(4), 75-90. http://dx.doi.org/10.2753/JOA0091-3367360406

Liu, E. C. L., Sinkovics, R. R., Pezderka, N., \& Haghirian, P. (2012). Determinants of consumer perceptions toward mobile advertising: A comparison between Japan and Austria. Journal of Interactive Marketing, 26(1), 21-32. http://dx.doi.org/10.1016/j.intmar.2011.07.002

Lu, L. C., Chang, W. P., \& Chang, H. H. (2014). Consumer attitudes toward blogger's sponsored recommendations and purchase intention: The effect of sponsorship type, product type, and brand awareness. Computers in Human Behavior, 34, 258-266. http://dx.doi.org/10.1016/j.chb.2014.02.007

MacKenzie, S. B., \& Lutz, R. J. (1989, April). An empirical examination of the structural antecedents of attitude toward the ad in an advertising pretesting context. Journal of Marketing, 53, 48-65. http://dx.doi.org/10.2307/1251413

Maclnnis, D. J., \& Jaworski, B. J. (1989, October). Information processing from advertisements: Toward an integrative framework. Journal of Marketing, 53, 1-23. http://dx.doi.org/10.2307/1251376

Malka, A. C. G. (2012). Generation Y: A significant generation. Retrieved November 20, 2014, from http://upetd.up.ac.za/thesis/available/etd-02192012-234156/.../05chapter5.pdf

Mao, J. (2014). Social media for learning: A mixed methods study on high school students' technology affordances and perspectives. Computers in Human Behavior, 33, 213-223. http://dx.doi.org/10.1016/j.chb.2014.01.002

Moise, D., \& Cruceru, A. F. (2014). An empirical study of promoting different kinds of events through various social media networks websites. Social and Behavioral Sciences, 109, 98-102. http://dx.doi.org/10.1016/j.sbspro.2013.12.426

Motwani, D., Shrimali, D., \& Agarwal, K. (2014). Customer's attitude towards social media marketing. Journal of Business Management \& Social Sciences Research, 3(4), 12-16.

Newell, J., Salmon, C. T., \& Chang, S. (2006). The hidden history of product placement. Journal of Broadcasting \& Electronic Media, 50(4), 575-594. http://dx.doi.org/10.1207/s15506878jobem5004_1

$\mathrm{Ng}$, C. S. P. (2013). Intention to purchase on social commerce websites across cultures: A cross-regional study. Information and Management, 50(8), 609-620. http://dx.doi.org/10.1016/j.im.2013.08.002

Park, C. W., MacInnis, D. J., Priester, J., Eisingerich, A. B., \& Iacobucci, D. (2006). Brand attachment and attitude towards product advertisements in social media strength: Conceptual and empirical differentiation of two, critical brand equity drivers. Journal of Marketing, 74(6), 1-17. http://dx.doi.org/10.1509/jmkg.74.6.1

Pew Research Internet Project. (2014). Social Networking Fact Sheet. Pew Research Center. Retrieved October 15, 2014, from http://www.pewinternet.org/fact-sheets/social-networking-fact-sheet/

Phang, G. I., \& Abdul Adis, A. A. (2009). The impact of advertising position and games experience on purchase intention in advergaming. Interdisciplinary Journal of Contemporary Research in Business, 1(4), 40-53.

Pinzaru, F, Savulescu, R., \& Mitan, A. (2013). New practices in marketing to generation y product placement in romanian pop music videos. International Journal of Academic Research, 5(4), 320-326. http://dx.doi.org/10.7813/2075-4124.2013/5-4/B.47

Ramayah, T., Jasmine, A. L. Y., \& Ignatius, J. (2013). An empirical inquiry on knowledge sharing among academicians in higher learning institutions. Minerva, 51(2), 131-154. http://dx.doi.org/10.1007/s11024-013-9229-7

Russell, C. A., \& Belch, M. (2005). A managerial investigation into the product placement industry. Journal of Advertising Research, 45(1), 73-92. http://dx.doi.org/10.1017/S0021849905050038 
Rutsaert, P., Pieniak, Z. A., Regan, A., McConnon, M., Kuttschreuter, M., Lores, N. ...Verbeke, W. (2014). Social media as a useful tool in food risk and benefit communication? A strategic orientation approach. Food Policy, 46, 84-93. http://dx.doi.org/10.1016/j.foodpol.2014.02.003

Safko, L., \& Brake, W. (2009). The social media bible: tactics, tools and strategies for business success (2nd ed.). John Wiley \& Sons.

Sallam, M. A. A. (2011). The impact of source credibility on saudi consumer's attitude toward print advertisement: The moderating role of brand familiarity. International Journal of Marketing Studies, 3(4), 63. http://dx.doi.org/10.5539/ijms.v3n4p63

Sekaran, U., \& Bougie, R. (2011). Research method for business, a skill-building approach (5th ed.). New York: John Wiley and Son Inc.

Tenenhaus, M., Vinzi, V. E., Chatelin, Y. M., \& Lauro, C. (2005). PLS path modelling. Computational Statistics \& Data Analysis, 48(1), 159-205. http://dx.doi.org/10.1016/j.csda.2004.03.005

Van Reijmersdal, E., Neijens, P. C., \& Smit, E. G. (2009). A new branch of advertising. Reviewing factors that influence reactions to product placement. Journal of Advertising Research, 49(4), 429-449. http://dx.doi.org/10.2501/S0021849909091065

Varnali, K., Yilmaz, C., \& Toker, A. (2012). Predictors of attitudinal and behavioral outcomes in mobile advertising: A field experiment. Electronic Commerce Research and Applications, 11(6), 570-581. http://dx.doi.org/10.1016/j.elerap.2012.08.002

W5 Insight. (2008). W5 on Millennials. Retrieved October 25, 2014, from http://www.w5insight.com/cms/wp-content/uploads/2011/07/W5-on-Millennials.pdf

Wang, J. C., \& Chang, C. H. (2013). How online social ties and product-related risks influence purchase intentions: A facebook experiment. Electronic Commerce Research and Applications, 12(5), 337-346. http://dx.doi.org/10.1016/j.elerap.2013.03.003

Wang, X., Yu, C. L., \& Wei, Y. J. (2012). Social media peer communication and impacts on purchase intentions: A consumer socialization framework. Journal of Interactive Marketing, 26(4), 198-208. http://dx.doi.org/10.1016/j.intmar.2011.11.004

Wang, Y. S., Yeh, C. H., \& Liao, Y. W. (2013). What drives purchase intention in the context of online content services? The moderating role of ethical self-efficacy for online piracy. International Journal of Information Management, 33(1), 199-208. http://dx.doi.org/10.1016/j.ijinfomgt.2012.09.004

Wilson, R. T., \& Till, B. D. (2011). Product placements in movies and on broadway. International Journal of Advertising, 30(3), 373-398. http://dx.doi.org/10.2501/IJA-30-3-373-398

$\mathrm{Xu}, \mathrm{D}$. (2007). The influence of personalization in effecting consumer attitudes toward mobile advertising consumer attitudes toward mobile advertising in China. The Journal of Computer Information Systems, 47(2), 9-19.

Yagci, I. M., Biswas, A., \& Dutta, S. (2009). Effects of comparative advertising format on consumer responses: The moderating effects of brand image and attribute relevance. Journal of Business Research, 62(8), 768-774. http://dx.doi.org/10.1016/j.jbusres.2008.03.005

Zeng, F., Huang, L., \& Dou, W. Y. (2010). Social factors in user perceptions and responses to advertising in online social networking communities. Journal of Interactive Advertising, 10(1), 1-13. http://dx.doi.org/10.1080/15252019.2009.10722159

\section{Copyrights}

Copyright for this article is retained by the author(s), with first publication rights granted to the journal.

This is an open-access article distributed under the terms and conditions of the Creative Commons Attribution license (http://creativecommons.org/licenses/by/3.0/). 